\title{
Optimal temperature for germination and seedling development in cowpea seeds
}

\section{Temperatura óptima para la germinación y el desarrollo de plántulas de semillas de frijol caupí}
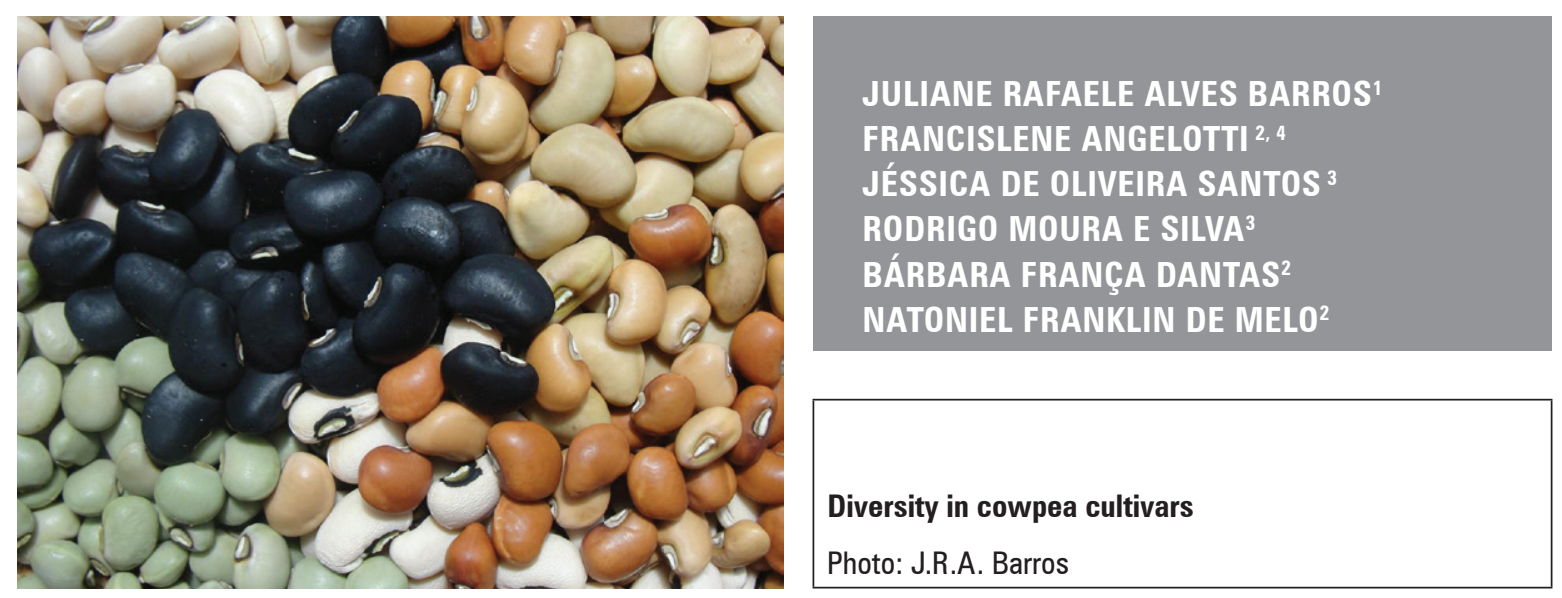

\section{ABSTRACT}

Temperature is one of the climatic elements that affect germination and seedling development. Thus, the objective of this study was to evaluate germination and seedling development in cowpea cultivars under increasing temperatures. Seeds from the cultivars Acauã, Carijó, Guariba, Gurguéia, Itaim, Juruá, Pajeú, Potengi, Pujante, Rouxinol, Tapahium, and Tumucumaque were kept in a germination chamber at temperatures of 20, $25,30,35$ and $40^{\circ} \mathrm{C}$, with a photoperiod of $12 \mathrm{~h}$. Cowpea seeds have optimal germination performance and seedling development at temperatures in the range of $30.49-35.48^{\circ} \mathrm{C}$. The cultivars presented a germination percentage above $91 \%$ under $40^{\circ} \mathrm{C}$; however, the seedlings were abnormal. The temperature $20^{\circ} \mathrm{C}$ provided germination above $96 \%$ but required a longer period to germinate. The temperature range between $30-35^{\circ} \mathrm{C}$ favored the germination speed index, an average time, and seed germination speed, with optimum temperatures varying between the cultivars. The highest normal seedling rate was observed at temperatures between 25 and $35^{\circ} \mathrm{C}$.

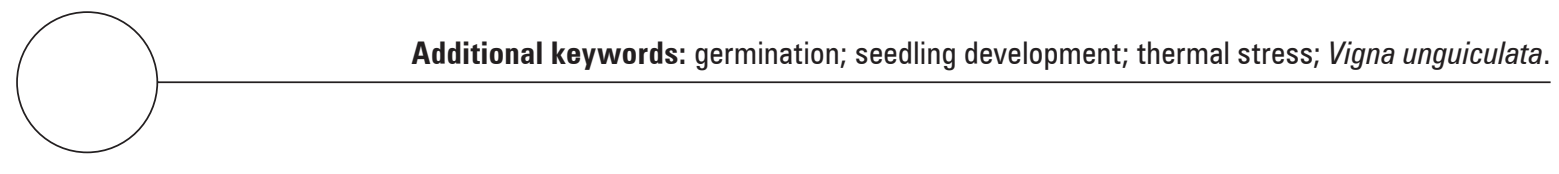

State University of Feira de Santana (Universidade Estadual de Feira de Santana), Feira de Santana (Brazil). ORCID Barros, J.R.A.: 0000-0002-0408-0904

2 Embrapa Semiárido, Petrolina (Brazil). ORCID Angelotti, F.: 0000-0001-7869-7264; ORCID Dantas, B.F.: 0000-0002-2375-9373; ORCID Melo, N.F.: 0000-0001-6888-4090

3 University of Pernambuco (Universidade de Pernambuco), Campus Petrolina, Petrolina (Brazil). ORCID Santos, J.O.: 0000-0002-1894-9359; ORCID Silva, R.M.: 0000-0002-2088-1955

4 Corresponding author. francislene.angelotti@embrapa.br 


\section{RESUMEN}

La temperatura es uno de los elementos climáticos que afectan la mayoría del proceso de germinación y el desarrollo de las plántulas. Por lo tanto, el objetivo de este estudio fue evaluar la germinación y el desarrollo de plántulas de los cultivares de frijol caupí a temperatura creciente. Para este propósito, las semillas de los cultivares Acauã, Carijó, Guariba, Gurguéia, Itaim, Juruá, Pajeú, Potengi, Pujante, Nightingale, Tapahium y Tumucumaque se mantuvieron en la cámara de germinación a temperaturas de 20, 25, 30, 35 y 40 $\mathrm{C}$, con fotoperiodo de 12 horas. Las semillas de frijol caupí tienen un rendimiento óptimo de germinación y desarrollo de plántulas a temperaturas en el rango de $30.49-35.48^{\circ} \mathrm{C}$. Los cultivares presentaron un porcentaje de germinación superior al $91 \%$ por debajo de $40^{\circ} \mathrm{C}$, sin embargo, no se observó formación de plántulas normales. La temperatura de $20^{\circ} \mathrm{C}$ proporcionó una germinación superior al 96\%, pero con un período más largo para germinar. El rango de temperatura entre 30 y $35^{\circ} \mathrm{C}$ favoreció el índice de velocidad de germinación, el tiempo promedio y la velocidad de germinación de la semilla, con temperaturas óptimas que varían entre los cultivares. La tasa más alta de plántulas normales se observó a temperaturas entre 25 y $35^{\circ} \mathrm{C}$.

Palabras clave adicionales: germinación; desarrollo de plántulas; estrés térmico; Vigna unguiculata.

Received for publication: 22-11-2019 Accepted for publication: 11-06-2020

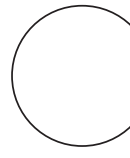

The cowpea (Vigna unguiculata (L.) Walp.) is a legume of great importance, not only in Brazil but also in other countries, especially on the African continent. In recent years, this crop has advanced in the domestic and international context, with increased production and market expansion (Vale et al., 2017). According to data from the Brazilian National Supply Company - CONAB (2019), in the 2018/2019 crop year, cowpea occupied an area of 1,327.5 thousand hectares in Brazil, with an estimated production of 651.8 thousand tons.

However, its yield is still considered low in Brazil. This low yield is associated with inadequate crop management and climatic conditions (Saboya et al., 2013). Temperature, for example, is one of the more influential climatic elements in crops because it can directly affect plant growth, yield, and seed germination and can also reduce seedling growth (Martinez et al., 2015).

Studies conducted by the Intergovernmental Panel on Climate Change (IPCC, 2013) showed that the average atmosphere temperature increased around $0.85^{\circ} \mathrm{C}$ from 1880 to 2012. Additionally, climate change scenarios also point to an increase in average temperature for the planet from 2.6 (most optimistic scenario) to $4.8^{\circ} \mathrm{C}$ (most pessimistic scenario) by 2100 . Experts say that this increase will not be uniform, with inter-annual and regional variations, and will lead to extreme climatic events, such as droughts and heavy rainfall (IPCC, 2013). According to Vale et al. (2017), cowpea development occurs in a wide temperature range, between 18 and $37^{\circ} \mathrm{C}$. However, the Brazilian Legislation indicates a seed analysis temperature of $25^{\circ} \mathrm{C}$ as optimal for seed germination (Brazil, 2009). Thus, the predicted increase in temperature may cause problems for seed germination.

Djanaguiraman et al. (2018) reported that plants will not only be exposed to higher average temperatures but also to more frequent short episodes of high temperatures. According to the authors, arid and semiarid regions are more vulnerable to climate change and extreme temperature events. Thus, vigorous seed germination and uniform seedling establishment are highly desirable, especially in these regions (Parmoon et al., 2015).

The early phase of plant life is one of the more important since plant establishment will depend on the ability of seeds and seedlings to overcome adverse environmental conditions (Melo Junior et al., 2018). Each species has a minimum, maximum, and optimal temperature for germination, and these cardinal temperatures indicate the limit in which germination of a particular species can occur (Mesgaran et al., 2017; Felix et al., 2018). The optimal temperature for 
maximum seed germination tends to differ among crops, and seed tolerance to high temperatures must be identified (Motsa et al., 2015). The selection of plants that are tolerant to temperature increases is of great importance, especially during the germination process, in order to facilitate the establishment of seedlings and uniformity in crops. Thus, the objective of this study was to evaluate the germination and seedling development of cowpea cultivars under increasing temperatures.

\section{MATERIALS AND METHODS}

This experiment was carried from April to May of 2018. Germination tests were performed in BOD (Biochemical Oxigen Demand) chambers, manufactured by Eletrolab Equipamentos para Laboratório, located in Brazil, equipped with white-fluorescent lamps, Philips $20 \mathrm{~W}$. This experiment was carried out in a completely randomized design, with four replicates of 50 seeds, in a $12 \times 5$ factorial scheme, with twelve cowpea cultivars (Acauã, Carijó, Guariba, Gurguéia, Itaim, Juruá, Pajeú, Potengi, Pujante, Rouxinol, Tapahium, and Tumucumaque), which were stored in air-conditioning, which reduced changes in seed quality, such as dormancy, moisture content and germination percentage (Brazil, 2009), and five temperatures $\left(20,25,30,35\right.$, and $\left.40^{\circ} \mathrm{C}\right)$, with a light regimen of $12 / 12 \mathrm{~h}$ (dark/light).

Initially, superficial disinfection of the seeds was done using a fungicide with the Alkylenobis (dithiocarbamate) chemical group at a ratio of $4 \mathrm{~g}$ (fungicide) to $1000 \mathrm{~g}$ of seeds. The seeds were arranged on a paper roll moistened with distilled water, at a ratio 2.5 times the dry paper weight. Germinated seeds were counted daily for a period of $12 \mathrm{~d}$, with the root protrusion equal to or greater than $2 \mathrm{~mm}$ as a parameter. After this period, normal and abnormal seedlings were counted, according to the rules for seed analysis (Brazil, 2009).

Germination percentage and kinetics indexes were estimated. The following parameters were evaluated: germination percentage $(G)$, average germination speed (AGS), germination speed index (GSI) and average germination time (AGT) using equations 1 to 4 , respectively. For review and instructions on how to apply and calculate these indexes, see Santana and Ranal (2000); Santana and Ranal (2004) and Ranal et al. (2009). The germination percentage was obtained with the daily counting of germinated seeds (Eq. 1).
The average germination time referred to the sum of the number of germinated seeds multiplied by the incubation time in days and divided by the sum of germinated seeds per day (Eq. 2). The germination speed was calculated with the inverse of the average germination time with daily counting (Eq. 3). The germination speed index was calculated from the sum of the number of germinated seeds per day divided by the respective number of days elapsed from sowing, corresponding to the number of germinated seeds over time, expressed in seed / day (Eq. 4).

$$
\begin{aligned}
& G=\frac{\sum_{i=1}^{k} n i}{A} * 100 \\
& A G T=\frac{\sum_{i=1}^{k} n i . t i}{\sum_{i=1}^{k} n i} \\
& A G S=\frac{\sum_{i}^{k} n i}{\sum_{i=1}^{k} n i . t i} \\
& G S I=\sum_{i=1}^{k} \frac{N i}{t i}
\end{aligned}
$$

where $K$ was the last day of observation, $A$ was total number of seeds placed to germinate, $n i$ was nonaccumulated number of germinated seeds, ti was number of days, and $N i$ was accumulated number of germinated seeds.

Normal seedlings had the potential to continue development and generate normal plants, with developed shoot and root system, while abnormal seedlings had essential structures that were damaged or absent (shoot and root system), according to the Brazilian Legislation for seed analysis (Brazil, 2009).

The data were submitted to variance analysis (ANOVA), and the means were compared with Scott Knott's test at $5 \%$ of significance using Sisvar v. 5.6 (Ferreira, 2011). The averages obtained for germination and germination speed index were compared with regression analysis.

\section{RESULTS AND DISCUSSION}

For all evaluated parameters: germination percentage, germination speed index, average germination time, average germination speed, normal (NS) and abnormal (AS) seedlings, the variance analysis presented significant $F$ values for cultivar and temperature and for the interaction cultivar $\times$ temperature (Tab. 1). 
Table 1. Summary of variance analysis with mean square for germination percentage (G), germination speed index (GSI), average germination time (AGT), average germination speed (AGS), and percentage values of normal (NS) and abnormal (AS) seedlings of different cowpea (Vigna unguiculate) cultivars, submitted to temperature increases.

\begin{tabular}{|l|c|c|c|c|c|c|c|}
\hline \multirow{2}{*}{ Variation source } & \multicolumn{7}{|c|}{ Mean square } \\
\cline { 2 - 8 } & DF & G & GSI & AGT & AGS & NS & AS \\
\hline Temperature (T) & 4 & $76.93^{* *}$ & $5013.06^{* *}$ & $9.26^{* *}$ & $1.71^{* *}$ & $39581.67^{* *}$ & $36690.60^{* *}$ \\
\hline Cultivar (C) & 11 & $12.34^{* *}$ & $122.65^{* *}$ & $0.32^{* *}$ & $0.05^{* *}$ & $2602.84^{* *}$ & $2537.27^{* *}$ \\
\hline T $\times$ C & 44 & $5.55^{* *}$ & $50.314^{* *}$ & $0.12^{* *}$ & $0.02^{* *}$ & $3199.53^{* *}$ & $3210.55^{* *}$ \\
\hline Residue & 180 & 2.53 & 5.64 & 0.014 & 0.0023 & 90.83 & 97.18 \\
\hline CV\% & & 1.61 & 7.2 & 6.84 & 7.7 & 19.3 & 19.96 \\
\hline
\end{tabular}

$\mathrm{DF}=$ degree of freedom; $\mathrm{CV}=$ coefficient of variation; ns = not significant, ${ }^{* *}$ significant at $1 \%$ of probability according to Scott-Knott's test.

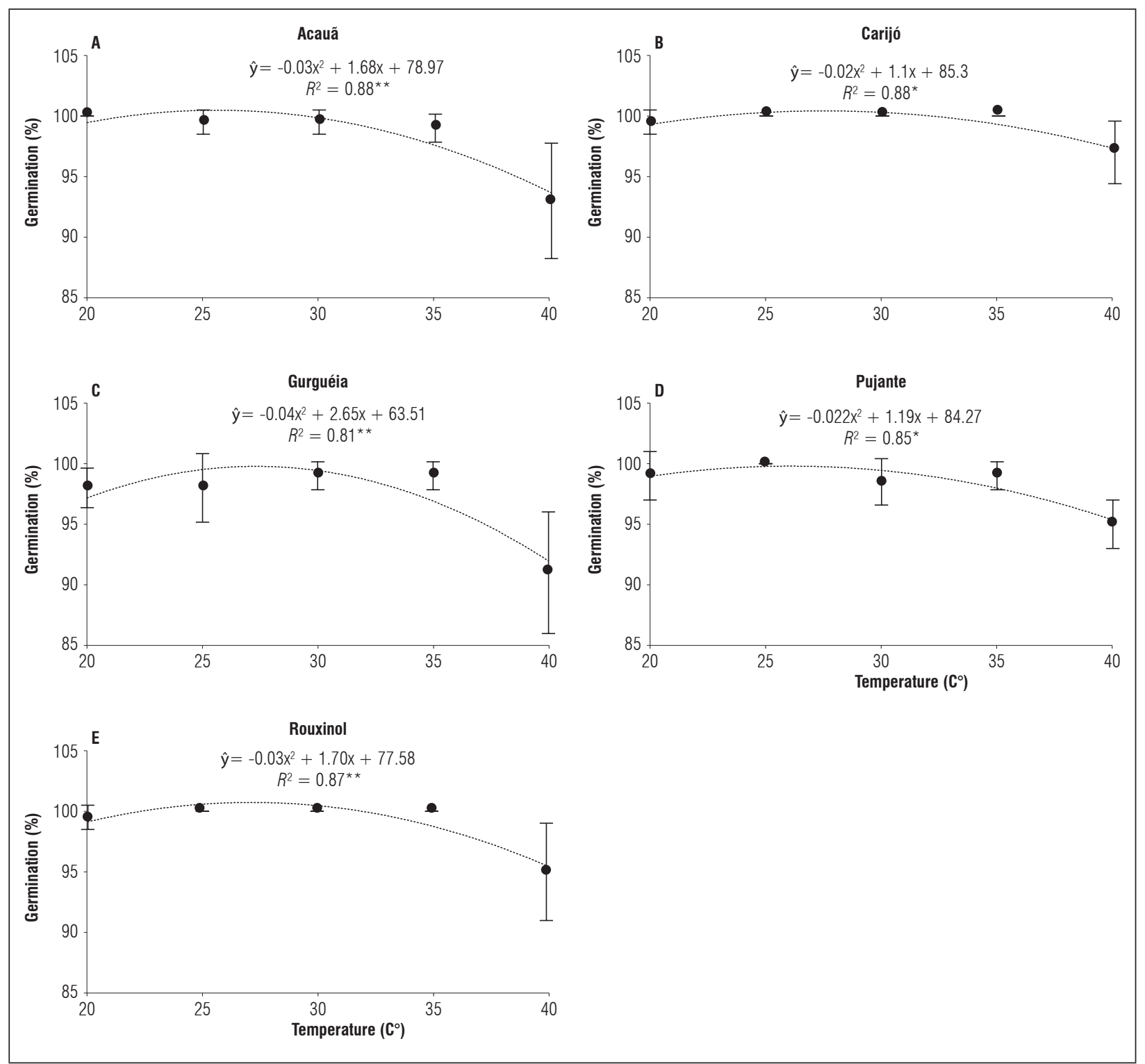

Figure 1. Percentage of seed germination of different cowpea (Vigna unguiculata) cultivars submitted to temperature increases. Significant regression coefficients with $P<0.01(* *)$ and $P<0.05\left({ }^{*}\right)$. 
The increase in temperature did not affect the germination of cowpea seeds, and the twelve cultivars presented germination percentages above $91 \%$ for all temperatures. A significant difference was observed only between the cultivars Acauã, Carijó, Gurguéia, Pujante and Rouxinol at $40^{\circ} \mathrm{C}$, where the lowest germination rate was observed in the seeds of the cultivars Acauã and Gurguéia, with a germination of 93 and $91 \%$, respectively (Fig. 1).

In the present study, according to the average data in the regression analysis, the higher germination rates occurred in a temperature ranging from 25.55 to $27.50^{\circ} \mathrm{C}$, where the germination percentage was between 99.75 to $100 \%$ for the cultivars Acauã, Carijó, Gurguéia, Pujante and Rouxinol (Fig. 1). Although the temperature $20^{\circ} \mathrm{C}$ provided germination percentages above $96 \%$, the seeds took longer to germinate, which meant a lower GSI, lower AGS and higher AGT. The seed germination percentages of Guariba, Itaim, Juruá, Pajeú, Potengi, Tapahium, and Tumucumaque cultivars were not influenced by the temperature increases.

Temperatures below the optimum result in a delay of seed germination because of reduced respiration-related enzyme activity and cellular metabolism (Taiz et al., 2017). Each species has a minimum temperature and a limit temperature, below and above which germination does not occur (Motsa et al., 2015). In addition, increasing temperature may reduce the percentage of seed germination by causing thermal stress, leading to inhibition of germination, and may also cause thermal dormancy, affecting seed viability (Bewley et al., 2013). This climatic element regulates enzymatic activities by promoting or inhibiting the synthesis of hormones, such as abscisic acid and ethylene, which affect seed germination (Gao-Takai et al., 2019). This occurs because elevated temperatures increase levels of abscisic acid and inhibit genes responsible for the synthesis of gibberellin, an essential hormone for activating the germinative process (Miransari et al., 2014). In addition, a high temperature can inhibit the synthesis of ethylene, another hormone responsible for seed germination.

Table 2 shows that the average data of the regression analysis indicated that the temperature range between $30-35^{\circ} \mathrm{C}$ favored the germination speed index, with optimum temperatures varying according to the cultivar. The highest average GSI was observed in seeds of cultivar Carijó, with a value of 48.61 at the optimal temperature of $30.40^{\circ} \mathrm{C}$ (Tab. 2).

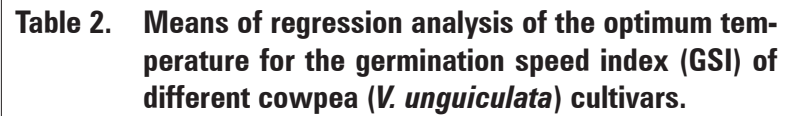

\begin{tabular}{|l|c|c|}
\hline \multicolumn{3}{|c|}{} \\
\hline Cultivars & Optimum temperature $\left.{ }^{\circ} \mathrm{C}\right)$ & GSI \\
\hline Acauã & 31.37 & 36.37 \\
\hline Carijó & 30.49 & 48.61 \\
\hline Guariba & 30.73 & 46.01 \\
\hline Gurguéia & 30.54 & 46.07 \\
\hline Itaim & 35.48 & 36.09 \\
\hline Juruá & 30.56 & 46.52 \\
\hline Pajeú & 31.64 & 39.66 \\
\hline Potengi & 31.61 & 39.53 \\
\hline Pujante & 31.75 & 36.40 \\
\hline Rouxinol & 30.96 & 40.93 \\
\hline Tapahium & 31.80 & 38.13 \\
\hline Tumucumaque & 30.51 & 47.82 \\
\hline
\end{tabular}

The cultivar Itaim had a temperature of 35.48 as the best for the GSI. This same temperature range favored AGT since the higher the germination speed index, the shorter the time for seed germination (Tab. 3).

During the germination process, temperature interferes with the water soak time and chemical reactions, thereby changing the germination speed. For common beans, the optimal temperature for GSI was $25-30^{\circ} \mathrm{C}$ (Zabot et al., 2008). Other genera of Fabaceae plants, such as fava beans and peas, present temperatures of 28.5 and $28.1^{\circ} \mathrm{C}$ as optimal for seed germination (Tribouillois et al., 2016). Common beans and these other legumes may be more sensitive to a temperature increase than cowpea because the present study had optimal seed performance at temperatures from 30.49 to $35.48^{\circ} \mathrm{C}$ (Tab. 2).

The Brazilian Northeast had a total annual cowpea production of 417.9 thousand tons in the 2018/2019 crop year (CONAB, 2019), higher than in other producing regions. In the Brazilian semiarid region, it is the main subsistence crop, planted practically throughout the year, either in a monoculture or intercrop system and in dry or irrigated areas (Vale et al., 2017). This region is has average temperatures of $26-28^{\circ} \mathrm{C}$. Thus, a scenario of a $4.8^{\circ} \mathrm{C}$ temperature increase, as predicted by the IPCC, will not affect the germination and establishment of cowpea seedlings. In addition, the results of this research update the optimal temperature used by the Seed Analysis Rules (SAR), 25ㄷ (Brazil, 2009). 
At sub and supra optimum temperatures of 20 and $40^{\circ} \mathrm{C}$, the seeds took longer to germinate, with a reduction in AGS (Tab. 3). This reduction indicated a physiological decline of the seed, which can occur either by reducing or stalling seed metabolism at suboptimal temperatures, or protein denaturation, causing a loss of enzymatic activity at elevated temperatures (Orzari et al., 2013).

The germination speed is a good index to evaluate the occupation of a species in a given environment, because rapid germination is characteristic of species whose strategy is to settle in the environment as quickly as possible, taking advantage of favorable environmental conditions (Melo Junior et al., 2018). Thus, through the germination speed index, the optimal temperature for cowpea germination is between $30.49-35.48^{\circ} \mathrm{C}$, varying according to the cultivar (Tab. 3). Orzari et al. (2013) confirmed that the optimal temperature is that in which the highest germination percentage was obtained within the shortest time. Temperature interferes with water soaking time and chemical reactions, changing the speed of germination (Gordin et al., 2012). This speed may be related to the physiological quality of the seeds, because the greater the vigor, the greater the speed and the germination rate (Pádua et al., 2010).

Even under thermal stress of $40^{\circ} \mathrm{C}$, all cultivars reached germination percentage from 91 to 100\%. However, this was not a good result, since under this condition there was no formation of normal seedlings in the evaluated cultivars (Fig. 2). Thus, environments with temperatures that are not optimal for each species can delay seedling emergence and reduce the stand due to the formation of small seedlings, confirming that environmental conditions are decisive in the process of crop establishment (Santos and Zonetti, 2009).

Regarding the percentage of normal and abnormal seedlings, the cultivars also responded differently to different temperatures. Temperatures between 25 and $35^{\circ} \mathrm{C}$ favored the formation of normal seedlings. This feature reinforces the adaptive capacity of the early development of cowpea under conditions of temperature increase. Other crops such as watermelon, for example, have the optimal temperature for seedling development at an average temperature of $25^{\circ} \mathrm{C}$ (Silva et al., 2018). The well-developed seedlings express the vigor of the seeds that gave rise to them, indicating that they can emerge faster and more uniformly, and establish themselves in adverse field conditions, thus allowing the expected stand to be obtained (Silva et al., 2017).

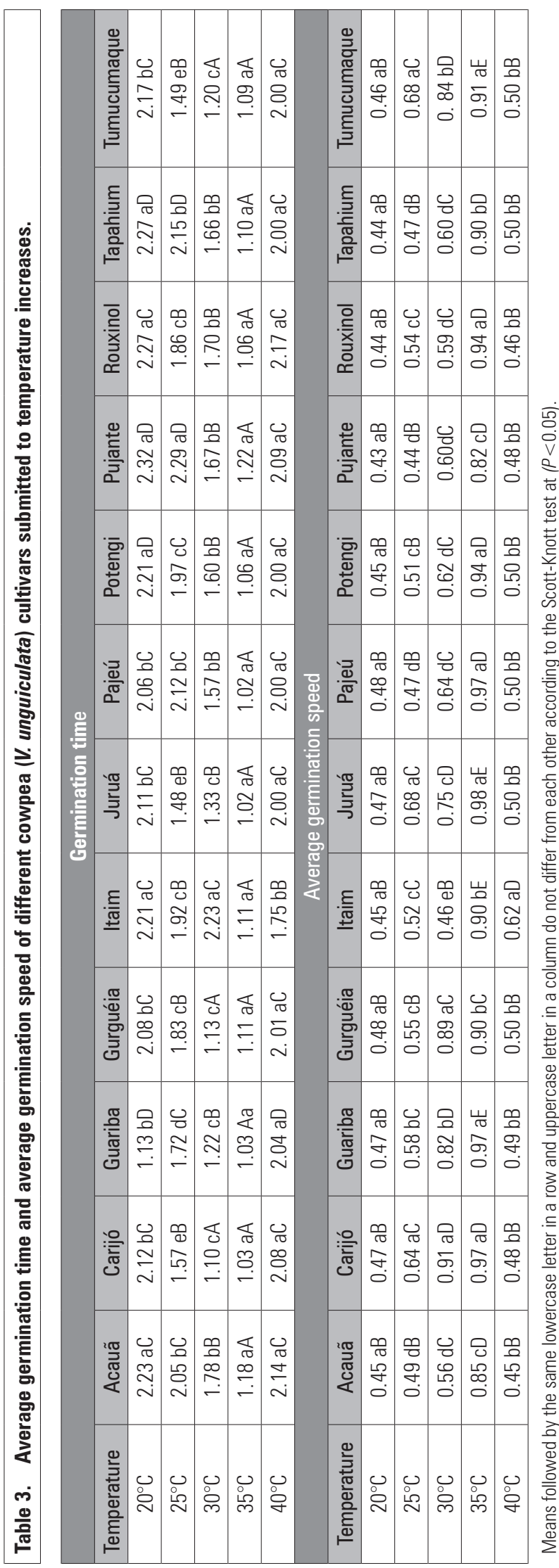



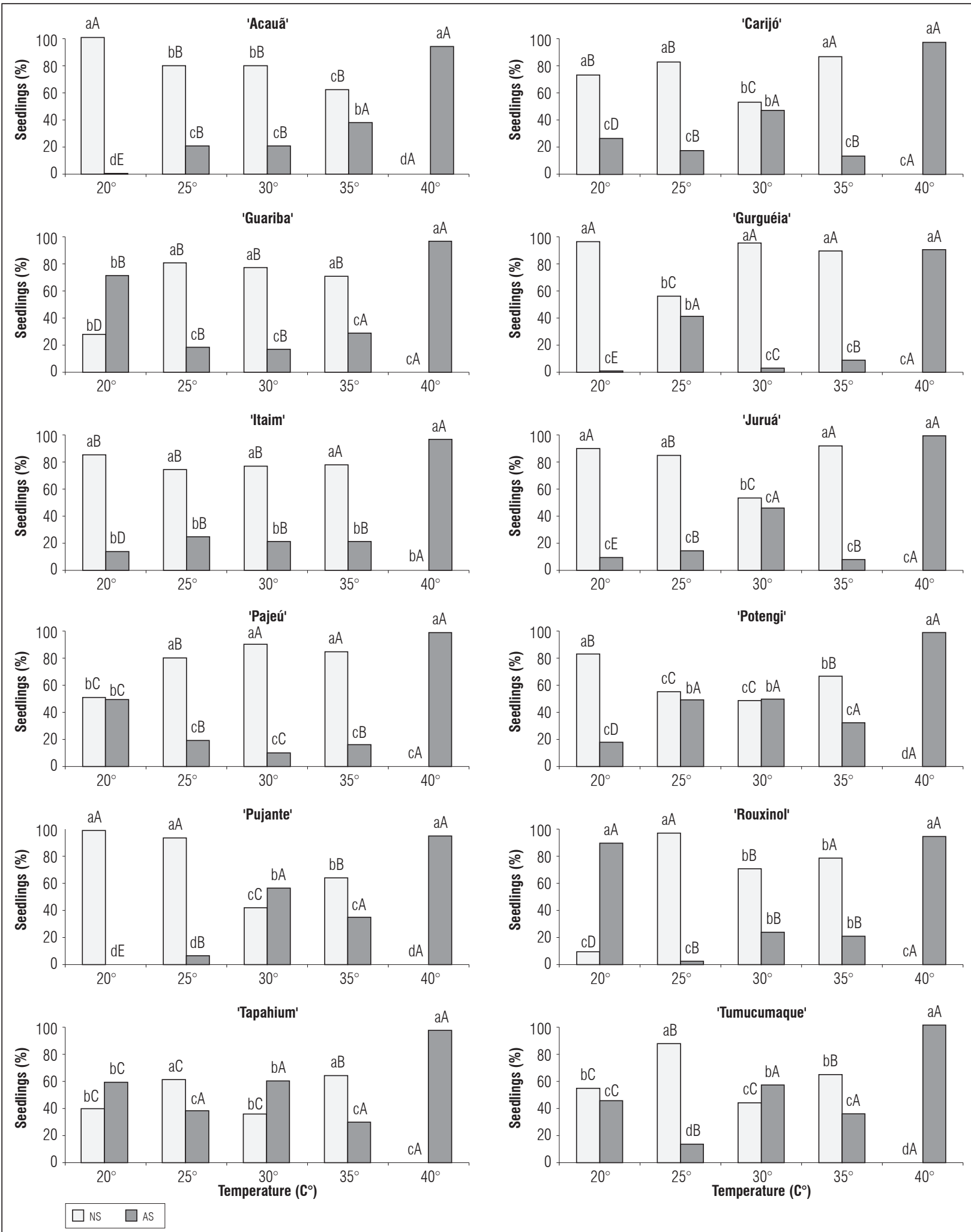

Figure 2. Percentage of normal seedlings (NS) and abnormal seedlings (AS) of cowpea (V. unguiculata) cultivars submitted to increased temperatures. * Lower case letters for temperatures and upper case for cultivars. 
Seed germination is a critical phase for seedling establishment in the culture medium, as they do not have the ability to withstand adverse environmental conditions, such as high temperatures. In the case of cowpea, the cultivars Acauã, Carijó, Guariba, Gurguéia, Itaim, Juruá, Pajeú, Potengi, Pujante, Rouxinol, Tapahium and Tumucumaque presented a satisfactory performance for the establishment of the plants, being necessary studies regarding the effect of temperature increase in the other phenological stages of the plant.

\section{CONCLUSION}

The increase in air temperature between $30-35^{\circ} \mathrm{C}$ have a positive impact on germination process of cowpea, showing higher percentage of germination within the shortest time and favored the formation of normal seedlings.

\section{ACKNOWLEDGMENTS}

The authors would like to thank the Foundation for the Support of Research of the State of Bahia (FAPESB) for funding the doctoral scholarship ( $\mathrm{N}^{\circ}$ BOL0419/2017).

Conflict of interests: The manuscript was prepared and reviewed with the participation of the authors, who declare that there exists no conflict of interest that puts at risk the validity of the presented results.

\section{BIBLIOGRAPHIC REFERENCES}

Bewley, J.D., J.D. Bradford, K. Hilhorst, and H. Nonogaki. 2013. Seeds: physiology of development, germination and dormancy. Springer, New York. Doi: 10.1007/978-1-4614-4693-4

Brazil, Ministério da Agricultura, Pecuária e Abastecimento. 2009. Regras para análise de sementes. MAPA/ ACS, Brasilia, DF.

CONAB, Companhia Nacional de Abastecimento. 2019. Acompanhamento da safra brasileira de grãos. v. 6 - Safra 2018/2019, n. 9 - Nono levantamento, Brasilia, DF.

Djanaguiraman, M., R. Perumal, I.A. Ciampitti, S.K. Gupta, and P.V.V. Prasad. 2018. Quantifying pearl millet response to high temperature stress: Thresholds, sensitive stages, genetic variability and relative sensitivity of pollen and pistil. Plant Cell Environ. 41(1), 993-1007. Doi: 10.1111/pce.12931
Felix, C.F., F.S. Araújo, M.D. Silva, C.S. Ferrari, and M.V. Pacheco. 2018. Estresse hídrico e térmico na germinação de sementes de Leucaena leucocephala (Lam.) de Wit. Rev. Bras. Cienc. Agrar. 13(2), 1-7. Doi: 10.5039/agraria.v13i2a5515

Ferreira, D.F. 2011. Sisvar: a computer statistical analysis system. Ciênc. Agrotec. 35(6), 1039-1042. Doi: 10.1590/S1413-70542011000600001

Gao-Takai, M., A. Katayama-Ikegami, K. Matsuda, H. Shindo, S. Uemae, and M. Oyaizu. 2019. A low temperature promotes anthocyanin biosynthesis but does not accelerate endogenous abscisic acid accumulation in red-skinned grapes. Plant Sci. 283(1), 165-176. Doi: 10.1016/j.plantsci.2019.01.015

Gordin, C.R.B., R.F. Marques, T.E. Masetto, and S.P.Q. Scalon. 2012. Germinação, biometria de sementes e morfologia de plântulas de Guizotia abyssinica Cass. Rev. Bras. Semen. 34(4), 619-627. Doi: 10.1590/ S0101-31222012000400013

IPCC, Intergovernmental Panel on Climate Change. 2013: Mudanças climáticas 2013: The Physical Science Basis. Contribuição do Grupo de Trabalho I para o Quinto Relatório de Avaliação do Painel Intergovernamental sobre Mudanças Climáticas [Stocker, T.F., D. Oin, G.-K. Plattner, M. Tignor, S.K. Allen, J. Boschung, A. Nauels, Y. Xia, V. Bex, and P.M. Midgley (eds.)]. Cambridge University Press, Cambridge, UK; New York, NY.

Martinez, C.A., E.A.D. Oliveira, T.R.P. Mello, and A.L.A. Marin. 2015. Respostas das plantas ao incremento atmosférico de dióxido de carbono e da temperatura. Rev. Bras. Geo. Fis. 8(6), 635-650. Doi: 10.26848/rbgf. v8.0.p635-650

Melo Junior, J.L.A., L.D.F. de A. Melo, J.C. Araujo Neto, and V.M. Ferreira. 2018. Germination and morphology of seeds and seedlings of Colubrina glandulosa Perkins after overcoming dormancy. Aust. J. Crop Sci. 12(1), 639-647. Doi: 10.21475/ajcs.18.12.04.pne980

Mesgaran, M.B., A. Onofri, H.R. Mashhadi, and R.D. Cousens. 2017. Water availability shifts the optimal temperatures for seed germination A modelling approach. Ecol. Model. 351(1), 87-95. Doi: 10.1016/j. ecolmodel.2017.02.020

Miransari, M. and D.L. Smith. 2014. Plant hormones and seed germination. Environ. Exp. Bot. 99(1), 110-121. Doi: 10.1016/j.envexpbot.2013.11.005

Motsa, M.M., M.M. Slabbert, W. Averbeke, and L. Morey. 2015. Effect of light and temperature on seed germination of selected African leafy vegetables. Sout. Afr. J. Bot. 99(1), 29-35. Doi: 10.1016/j.sajb.2015.03.185

Orzari, I., P.A. Monquero, F.C. Reis, R.S. Sabbag, and A.C.S. Hirata. 2013. Germinação de espécies da família Convolvulaceae sob diferentes condições de luz, 
temperatura e profundidade de semeadura. Pl. Dan. 31(1), 53-61. Doi: 10.1590/S0100-83582013000100006

Pádua, G.P de., R.K. Zito, N.E. Arantes, and J.B. Rança Neto. 2010. Influência do tamanho da semente na qualidade fisiológica e na produtividade da cultura da soja. Rev. Bras. Semen. 32(3), 09-16. Doi: 10.1590/ S0101-31222010000300001

Parmoon, G., S.A. Moosavi, H. Akbari, and A. Ebadi. 2015. Quantifying cardinal temperatures and thermal time required for germination of Silybum marianum seed. Crop J. 3(1), 145-151. Doi: 10.1016/j.cj.2014.11.003

Ranal, M.A., D.G. Santana, W.R. Ferreira, and C. Mendes-Rodrigues. 2009. Calculating germination measurements and organizing spreadsheets. Braz. J. Bot. 32, 849-855. Doi: 10.1590/S0100-84042009000400022

Saboya, R.C.C., P.R.S. Borges, L.M.F. Saboya, F.P. dos R. Monteiro, A.E.A. Souza, and A.F. Santo. 2013. Response of cowpea to inoculation with nitrogen-fixing strains in Gurupi-Tocantins State. J. Biot. Biod. 4(1), 40-48. Doi: 10.20873/jbb.uft.cemaf.v4n1.saboya

Santana, D.G. and M.A. Ranal. 2000. Análise estatística da germinação. Rev. Bras. Fisi. Veg. 12, 175-204.

Santana, D.G. and M.A. Ranal. 2004. Análise da germinação: um enfoque estatístico. Editora Universidade de Brasília, Brasilia, DF.
Santos, G.A. and P.C. Zonetti. 2009. Influência da temperatura na germinação e desenvolvimento do girassol (Helianthus annuus L.). Rev. Inic. Cien. Ces. 11(1), 23-27.

Silva, R.C.B., M. do N. Araujo, F.L.S. Ornellas, and B.F. Dantas. 2018. Thermal stress and physiological changes in watermelon seeds. Rev. Pes. Agr. Trop. 48(1), 6674. Doi: 10.1590/1983-40632018v4850404

Silva, R.B., V.P. Matos, S.G.G. Farias, L.H.M. Sena, and D.Y.B.O. Silva. 2017. Germinação e vigor de plântulas de Parkia platycephala Benth. em diferentes subustratos e temperaturas. Rev. Ciênc. Agron. 48(1), 142-150. Doi: 10.5935/1806-6690.20170016

Taiz, L., E.Z.I.M. Moller, and A. Murphy. 2017. Fisiologia e desenvolvimento vegetal. $6^{\text {th }} \mathrm{ed}$. Artmed, Porto Alegre.

Tribouillois, H., C. Durr, D. Demilly, M.H. Wagner, and E. Justes. 2016. Determination of germination response to temperature and water potential for a wide range of cover crop species and related functional groups. PLoS One 11(1). Doi: 10.1371/journal.pone.0161185

Vale, J.C., C. Bertini, and A. Borém. 2017. Feijão-caupi: do plantio à colheita. Editora UFV, Viçosa, Brazil.

Zabot, L., L.M.C. Dutra, D.C. Garcia, N.L. Menezes, and M.P. Ludwig. 2008. Temperatura e qualidade fisiológica no crescimento de plântulas de Feijoeiro. Rev. Bras. Agr. 14(4), 60-64. 